\title{
Geomedia
}

Majalah Ilmiah dan Informasi Kegeografian

Geomedia Vol. 19 No. 1 Tahun 2021 | 26 - 34

https://journal.uny.ac.id/index.php/geomedia/index

\section{Valuasi ekonomi jasa ekosistem mangrove di wilayah pesisir kota Pekalongan}

\author{
Tiara Sarastika ${ }^{a, 1^{*}}$ \\ a Jurusan Pendidikan Geografi, Fakultas Ilmu Sosial, Universitas Negeri Yogyakarta, Yogyakarta, Indonesia \\ 1 tiarasarastika@uny.ac.id \\ *korespondensi penulis
}

\begin{tabular}{ll}
\hline \multicolumn{2}{l}{ Informasi artikel } \\
\hline Sejarah artikel & \\
Diterima & $: 17$ April 2021 \\
Revisi & $: 18$ Mei 2021 \\
Dipublikasikan & $:$ 31 Mei 2021 \\
\hline
\end{tabular}

Kata kunci:

Jasa ekosistem

Mangrove

Valuasi ekonomi

\begin{abstract}
A B S T R A K
Jasa ekosistem mangrove terbagi menjadi jasa penyedia, jasa pendukung, jasa kebudayaan, dan jasa pengaturan yang bermanfaat bagi manusia dan lingkungan. Jasa pengaturan ekosistem mangrove berfungsi sebagai perlindungan terhadap ancaman bahaya pesisir, seperti gelombang pasang, angin badai, dan erosi. Penelitian ini bertujuan untuk mengkaji valuasi ekonomi jasa pengaturan ekosistem mengarove di wilayah pesisir Kota Pekalongan. Metode yang digunakan adalah survei lapangan untuk mengumpulkan data kondisi eksisting ekosistem mengrove dan wawancara mendalam untuk memperoleh informasi nilai pengganti dari jasa pengaturan ekosistem mangrove. Data yang diperoleh dianalisis secara spasial dan deskriptif. Valuasi ekonomi jasa ekosistem dihitung menggunakan metode pengganti. Hasil penelitian menunjukkan bahwa peran jasa ekosistem mangrove dalam mengurangi risiko genangan banjir antara lain meredam gelombang laut, memperkuat tanggul di sekeliling tambak, dan mengurangi erosi pada tanggul sungai supaya air tidak menggenangi permukiman dan perikanan tambak. Penilaian jasa ekosistem mangrove di wilayah pesisir Kota Pekalongan menunjukkan nilai kehilangan sejumlah $13.664,7$ milyar rupiah untuk penggunaan lahan berupa permukiman, sedangkan untuk perikanan tambak sebesar 24.096,275 milyar rupiah. Penilaian ekonomi secara berkala dan kontinyu akan membantu dalam pengelolaan ekosistem mangrove berkelanjutan.
\end{abstract}

Keywords:

Ecosystem services

Mangrove

Economic Valuation

\section{A B S T R A C T}

Mangrove ecosystem services are divided into provisioning services, supporting services, cultural services and regulating services that beneficial for humans and environment. Regulating services of mangrove ecosystem as protection of coastal hazard, like tidal wave, wind storms, and erosion. This study aims to assess the economic valuation of regulating services of mangrove ecosystem based on society's perception in coastal area of Pekalongan City. The method used are field survey to collect data on the condition of existing mangrove ecosystem and indepth interview to get information about replacement value of regulating services of mangrove ecosystem. Economic valuation of ecosystem services is calculated using the replacement method. The results showed that the role of mangrove ecosystem services in reducing the risk of flood inundation, among others drown sea waves, strengthen levees on the edge of the pond, and reducing erosion on the embankment of the river so that water does not get into the settlements and fishponds. Assessment of mangrove ecosystem services in disaster risk reduction in coastal areas of Pekalongan City is $13.664,7$ billion rupiah for settlements, while for the fishing pond is 
24.096,275 billion rupiah. Periodic and continuous economic assessments will assist in the sustainable management of mangrove ecosystems.

(C) 2021 (Tiara Sarastika). All Right Reserved

\section{Pendahuluan}

Wilayah pesisir memiliki karakteristik lingkungan yang unik, dinamis, dan rentan terhadap perubahan lingkungan. Proses geomorfologi yang terjadi dengan beragam intensitas menyebabkan wilayah pesisir rentan terhadap bahaya alam. Berbagai bencana di wilayah pesisir dipicu oleh perubahan iklim global sehingga muncul fenomena abrasi, gelombang pasang, banjir rob, banjir luapan sungai, dan angin badai (Marfai dan King 2008a, Marfai dkk 2009). Dinamika wilayah kepesisiran juga dipengaruhi oleh aktivitas manusia dalam memanfaatkan lahan, seperti kegiatan pertanian, permukiman, pelabuhan, industri, dan pariwisata.

Wilayah pesisir Kota Pekalongan merupakan bagian dari pesisir utara Pulau Jawa yang rentan terhadap banjir. Karakteristik Kota Pekalongan yang memiliki muara dan banyak saluran irigasi menyebabkan air laut masuk ke daratan. Kondisi ini diperparah pula ketika musim penghujan dengan debit air yang tinggi dapat memicu banjir sungai di muara. Air rob ditambah dengan air hujan pada penampang sungai menyebabkan air meluap ke kanan kiri sungai dan masuk ke saluran irigasi. Kondisi ini mengakibatkan kerugian pada berbagai ekosistem baik secara fisik, sosial, dan ekonomi yaitu mangrove, pertanian, dan perikanan tambak (Marfai, 2014a).

Mangrove merupakan salah satu potensi ekosistem di wilayah pesisir Kota Pekalongan. Arief (2003) menjelaskan mangrove merupakan formasi hutan khas daerah tropika dan sedikit subtropika, terdapat di pantai rendah dan tenang, berlumpur, sedikit berpasir, serta mendapat pengaruh pasang surut air laut. Mangrove juga merupakan mata rantai penting dalam pemeliharaan keseimbangan siklus biologi di suatu perairan. Berdasarkan Keputusan Walikota Pekalongan Nomor 532/02.a Tahun 2013 menjelaskan ekosistem mangrove di Kota Pekalongan mulai dikembangkan sebagai lahan konservasi melalui pembebasan lahan seluas 5,7 ha di tahun 2011 dan akan diperluas $\pm 3,8$ ha di tahun 2012. Selain itu, dilakukan pengembangan ekowisata mangrove melalui Pusat Informasi Mangrove (PIM) atau Pusat Restorasi Pembelajaran Mangrove (PRPM).
Ekosistem mangrove memberikan jasa yang bermanfaat bagi kehidupan manusia, yaitu jasa penyedia, pendukung, pengaturan, dan kebudayaan (Millenium Ecosystem Assessment 2005, TEEB 2010). Sehubungan dengan kondisi pesisir Kota Pekalongan yang rawan terhadap bencana, baik banjir rob, banjir luapan sungai, abrasi, dan angin kencang membutuhkan perlindungan alami melalui jasa pengaturan ekosistem mangrove. Jasa pengaturan merupakan jasa yang dihasilkan oleh ekosistem terkait dengan pengaturan sistem dan proses yang terjadi di alam, baik pengatur iklim, udara, air, maupun bencana alam. Ekosistem mangrove mampu menangkap sedimen, menahan gelombang, memperkuat tanggul di tepi sungai, dan menyeimbangkan iklim global.

Harahap (2010) menjelaskan bahwa pendekatan yang digunakan dalam melakukan penilaian manfaat ekosistem hutan mangrove didekati dengan menggunakan konsep penilaian ekonomi total (total economic valuation/ TEV). Total valuasi ekonomi dilakukan untuk menduga total kontribusi ekonomi dari sebuah ekosistem tertentu kepada masyarakat. Penghitungan TEV jasa pengaturan ekosistem mangrove berfungsi memberikan gambaran nilai ekonomi ekosistem mangrove dalam pengurangan risiko bencana, sehingga masyarakat mengetahui berapa besar nilai kehilangan yang akan diperoleh jika tidak mempertahankan ekosistem yang ada.

Salah satu permasalahan dalam upaya mengurangi risiko bencana di wilayah pesisir adalah belum atau tidak adanya informasi terkait nilai ekonomi mangrove sebagai dasar penentuan program konservasi mangrove. Nilai TEV ekosistem mangrove perlu diperhitungkan dalam menyusun kebijakan pengelolaan wilayah pesisir sehingga alokasi dan alternatif penggunaannya dapat ditentukan secara benar dan mengenai sasaran (Marre et al., 2015). Penelitian terkait valuasi ekonomi jasa ekosistem mangrove ini penting dilakukan sebagai bagian dari pengelolaan ekosistem mangrove yang berkelanjutan. 


\section{Metode}

Penelitian ini berlokasi di wilayah pesisir Kota Pekalongan, Provinsi Jawa Tengah. Kriteria pemilihan lokasi dilakukan secara non probability sampling dengan teknik purposive sampling, yaitu mempertimbangkan beberapa hal sebagai berikut:

a. Keberadaan mangrove berdasarkan Kawasan Pantai Berhutan Bakau sesuai Peta Rencana Pola Ruang Kota Pekalongan dan Peta Penetapan Kawasan Strategis Lingkungan (Perda Kota Pekalongan Nomor 30 Tahun 2011).

b. Daerah terdampak abrasi dan genangan banjir berdasarkan Peta Kawasan Rawan Bencana Kota Pekalongan (Perda Kota Pekalongan Nomor 30 Tahun 2011)

Secara administratif, daerah penelitian meliputi kelurahan yang berbatasan langsung dengan pesisir. Semua kelurahan terpilih ini berada di Kecamatan Pekalongan Utara yang dirinci pada Tabel 1.

Tabel 1. Kelurahan yang Terpilih sebagai Lokasi Penelitian

\begin{tabular}{lrr}
\hline Kelurahan (Sampel) & Luas $\mathbf{( k m}^{\mathbf{2}}$ ) & Luas (\%) \\
\hline Degayu & 3,37 & 25,47 \\
Krapyak & 3,79 & 28,65 \\
Panjang Wetan & 1,41 & 10,66 \\
Panjang Baru & 0,94 & 7,11 \\
Kandang Panjang & 1,51 & 11,41 \\
Bandengan & 2,21 & 16,70 \\
\hline Total & $\mathbf{1 3 , 2 3}$ & $\mathbf{1 0 0 , 0 0}$
\end{tabular}

Sumber: Kecamatan Pekalongan Utara Dalam Angka 2019

Penelitian ini menggunakan metode deskriptif kualitatif dan kuantitatif. Tujuan penggunaan metode kualitatif untuk memberikan informasi kondisi eksisting dan rencana pengembangan ekosistem mangrove di wilayah pesisir Kota Pekalongan. Penggunaan metode kuantitatif digunakan untuk memberikan informasi nilai jasa pengaturan ekosistem mangrove dalam satuan rupiah untuk penggunaan lahan permukiman dan perikanan tambak.

Pengumpulan data dilakukan dengan kegiatan survei lapangan dan wawancara mendalam (indepth interview). Survei lapangan digunakan untuk mengamati kondisi eksisting mangrove, sedangkan wawancara mendalam untuk mengetahui besarnya nilai ekonomi jasa ekosistem mangrove. Narasumber yang digunakan untuk wawancara mendalam ada 2, yaitu perwakilan dari Dinas Kelautan dan Perikanan Kota Pekalongan untuk mengetahui besarnya produktivitas pada lahan perikanan tambak dan harga jualnya. Narasumber yang kedua adalah perwakilan dari Kantor Kecamatan Pekalongan Utara untuk mengetahui besarnya nilai pengganti dalam membangun rumah di wilayah setempat.

Penilaian jasa pengaturan ekosistem mangrove menggunakan perhitungan TEV. Pendekatan yang digunakan yaitu contingent valuation yaitu metode pendekatan yang mengandalkan pendapat seseorang dengan cara survei langsung di lapangan. Jasa pengaturan ekosistem mangrove dalam pengurangan risiko bencana berupa perlindungan terhadap permukiman penduduk dan perikanan tambak dari bencana rob dan banjir luapan sungai yang tidak memiliki ekosistem mangrove sebagai penghalangnya. Penghitungan TEV ini didasarkan pada besarnya nilai objek yang terlindungi oleh ekosistem mangrove dari bencana alam. Seandainya ekosistem mangrove tersebut hilang maka objek tersebut tidak terlindungi lagi sehingga potensial terkena bencana alam dan akan mengalami kerugian. Nilai diperoleh berdasarkan pendekatan pasar dengan metode pengganti (replacement method) yaitu besarnya uang yang dibutuhkan untuk dapat mengembalikan atau mengganti permukiman dan lahan perikanan tambak yang berpotensi rusak untuk kembali pada kondisi semula sebelum terkena bencana alam (Satriagasa, 2015).

Perhitungan nilai pengganti untuk permukiman (RBg) merupakan jumlah total dari biaya membangun baru bangunan tiap kategorinya dengan satuan rupiah. Nilai tiap tipe bangunan (dalam rupiah) dihitung berdasarkan biaya membangun baru (rupiah). Nilai membangun baru merupakan penjumlahan dari biaya langsung dengan biaya tidak langsung dalam rupiah $/ \mathrm{m}^{2}$. Biaya langsung terkait dengan komponen bangunan yaitu struktur kerangka dan $\operatorname{atap}(\mathrm{St})$, penutup atap $(\mathrm{A})$, plafon $(\mathrm{PI})$, dinding (D), dan lantai (L). Biaya tidak langsung terkait dengan jasa konstruksi dan perijinan yaitu profesional fee seperti fee konsultan perencana dan konsultan pengawas (PF), biaya perijinan mendirikan bangunan atau IMB (I), dan keuntungan 
kontraktor (K). Secara matematis biaya langsung $(\mathrm{BL})$, biaya tidak langsung (BTL), dan nilai pengganti bangunan (RBg) dapat dituliskan sebagai berikut (MAPPI, 2013 dalam Satriagasa, 2015).

$\mathrm{BL}$ (biaya langsung $)=\mathrm{St}+\mathrm{A}+\mathrm{PI}+\mathrm{D}+\mathrm{L}$

$\mathrm{BTL}$ (biaya tidak langsung $)=\mathrm{PF}+\mathrm{I}+\mathrm{K}$

$\mathrm{RBg}=\{(1)+(2)\} \times$ luas bangunan terdampak $\left(\mathrm{m}^{2}\right)$

Nilai pengganti untuk perikanan tambak (RPt) merupakan jumlah total nilai perikanan tambak dari setiap jenis budidaya tambak dengan satuan rupiah. Nilai tiap jenis budidaya tambak (dalam rupiah) dihitung berdasarkan nilai jual komoditas budidaya tambak (rupiah/ $\mathrm{kg}$ ) dikalikan dengan produktivitas $(\mathrm{kg} / \mathrm{Ha} / \mathrm{th})$ dikalikan dengan luasan lahan budidaya tambak $(\mathrm{Ha})$. Secara matematis nilai pengganti perikanan tambak (RPt) dituliskan sebagai berikut.

$\mathrm{RPt}=$ luas terdampak (ha) $\mathrm{x}$ produktivitas $(\mathrm{kg} / \mathrm{ha} / \mathrm{th}) \times$ harga jual $(\mathrm{Rp} / \mathrm{kg})$

$\mathrm{RPt}=$ nilai pengganti perikanan tambak $(\mathrm{Rp})$

\section{Hasil dan pembahasan}

Potensi ekosistem mangrove yang berkembang di wilayah pesisir memiliki berbagai jasa ekosistem, yaitu jasa penyedia, jasa pendukung, jasa pengaturan, dan jasa kebudayaan. Jasa pengaturan ekosistem mangrove memiliki fungsi ekologi yang dapat digunakan untuk mengurangi risiko bencana. Ancaman bencana di wilayah pesisir Kota Pekalongan antara lain rob, banjir luapan sungai, erosi laut, pasang surut, dan angin badai. Respon ekosistem mangrove terhadap ancaman bencana di pesisir antara lain meredam laju gelombang dan erosi pantai, menahan angin badai, menangkap sedimen, menstabilkan iklim mikro dan mengendalikan iklim global.

Hal yang berbeda disampaikan Lugina, M. dkk (2019) terkait manfaat dari ekosistem mangove, yaitu terdiri dari nilai guna langsung (hasil tangkapan ikan), nilai guna tidak langsung (sebagai pemecah ombak), dan nilai pilihan (nilai keanekaragaman hayati). Nilai guna tidak langsung menyumbang nilai tertinggi pada perhitungan nilai ekonomi total, padahal nilai ini sering diabaikan oleh masyarakat ataupun pemerintah. Hal tersebut menunjukkan bahwa penilaian terhadap besarnya jasa pengaturan ekosistem yaitu pengurangan risiko bencana penting untuk dilakukan.

Persebaran ekosistem mangrove secara eksisting yang terdapat di wilayah pesisir Kota Pekalongan dijelaskan melalui peta pada Gambar 1. Luasan potensi ekosistem mangrove sebesar 615,8 ha, dengan lahan yang sudah ditanami seluas 312 ha dan lahan yang belum ditanami seluas 303,8 ha, dijelaskan secara rinci pada Tabel 2. Mangrove tersebar merata sepanjang pantai yang berfungsi untuk meredam gelombang laut yang menuju daratan. Mangrove yang berada di kanan kiri sungai berfungsi sebagai tanggul alami dan mengurangi aktivitas erosi. Mangrove yang ditanam disekeliling tambak berfungsi untuk menguatkan tanggul di sekeliling tambak.

Wilayah pesisir Kota Pekalongan memiliki wilayah konservasi mangrove yang dikenal dengan Pusat Informasi Mangrove (PIM). PIM merupakan kawasan pusat pembelajaran ekosistem mangrove yang digunakan sebagai kawasan konservasi, tempat edukasi, dan memberikan peluang penelitian dari berbagai pihak. Lokasi PIM berada di Kelurahan Bandengan dan Kelurahan Kandang Panjang dengan luas 9,5 ha. Potensi lahan ekosistem mangrove yang belum ditanami merupakan lahan yang sudah tergenang air dan tidak mampu dimanfaatkan untuk penggunaan lahan lain. Kondisi eksisting tumbuhan mangrove di wilayah pesisir Kota Pekalongan dijelaskan dalam Gambar 2.

Keanekaragaman jenis mangrove di pesisir Kota Pekalongan dibedakan menjadi mangrove sejati, mangrove ikutan, dan vegetasi lain. Mardiatno dkk (2012) menjelaskan bahwa ekosistem mangrove terdapat di sepanjang pantai dengan kelimpahan yang cukup rendah. Pantai sebelah barat lebih sedikit vegetasinya daripada pantai sebelah timur. Jenis mangrove yang terdapat di Kecamatan Pekalongan Utara secara rinci diperlihatkan pada Tabel 3. Perubahan penggunaan lahan dari peruntukan mangrove menjadi perikanan tambak intensif terjadi dalam skala besar di wilayah Asia (Barbier et al., 2011). Hal ini sesuai dengan fenomena di wilayah penelitian, pada beberapa lokasi juga terlihat aktivitas manusia berupa membuka daerah tambak, memasang pagar pembatas, mencari ikan dan kepiting, serta sisa-sisa penebangan bakau. 


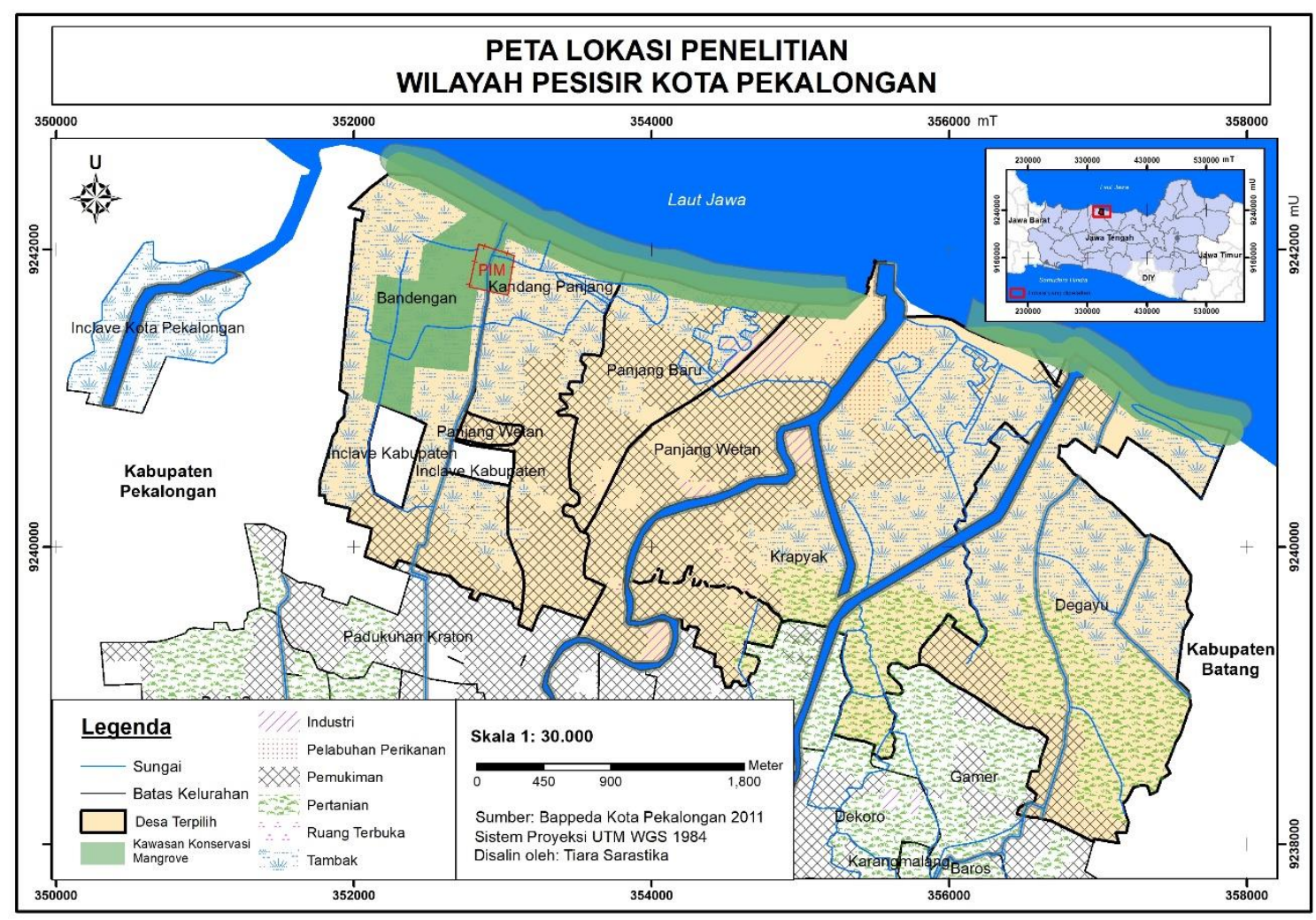

Gambar 1. Peta lokasi penelitian yang menunjukkan distribusi ekosistem mangrove Tabel 2. Luasan Kawasan Mangrove di Kota Pekalongan

\begin{tabular}{clrrrrrr}
\hline \multirow{2}{*}{ No } & \multirow{2}{*}{ Kelurahan } & \multicolumn{2}{c}{ Potensi Lahan } & \multicolumn{3}{c}{$\begin{array}{c}\text { Lahan yang Telah } \\
\text { Ditanami }\end{array}$} & \multicolumn{2}{c}{$\begin{array}{c}\text { Lahan yang Belum } \\
\text { Ditanami }\end{array}$} \\
\cline { 3 - 8 } & & \multicolumn{1}{c}{ ha } & \multicolumn{1}{c}{$\%$} & \multicolumn{1}{c}{ ha } & \multicolumn{1}{c}{$\%$} & \multicolumn{1}{c}{ ha } & \multicolumn{1}{c}{$\%$} \\
\hline 1 & Degayu & 185,8 & 30,17 & 60 & 19,23 & 125,8 & 41,41 \\
2 & Krapyak & 104,1 & 16,90 & 60 & 19,23 & 44,1 & 14,52 \\
3 & Panjang Wetan & 46,1 & 7,49 & 30 & 9,62 & 16,1 & 5,30 \\
4 & Panjang Baru & 32,4 & 5,26 & 30 & 9,62 & 2,4 & 0,78 \\
5 & Kandang Panjang & 83,5 & 13,56 & 60 & 19,23 & 23,5 & 7,74 \\
6 & Bandengan & 163,9 & 26,62 & 72 & 23,07 & 91,9 & 30,25 \\
\hline Total & & $\mathbf{6 1 5 , 8}$ & $\mathbf{1 0 0}$ & $\mathbf{3 1 2}$ & $\mathbf{1 0 0}$ & $\mathbf{3 0 3 , 8}$ & $\mathbf{1 0 0}$ \\
\hline
\end{tabular}

Sumber: Keputusan Walikota Pekalongan Nomor 532/02.a Tahun 2013
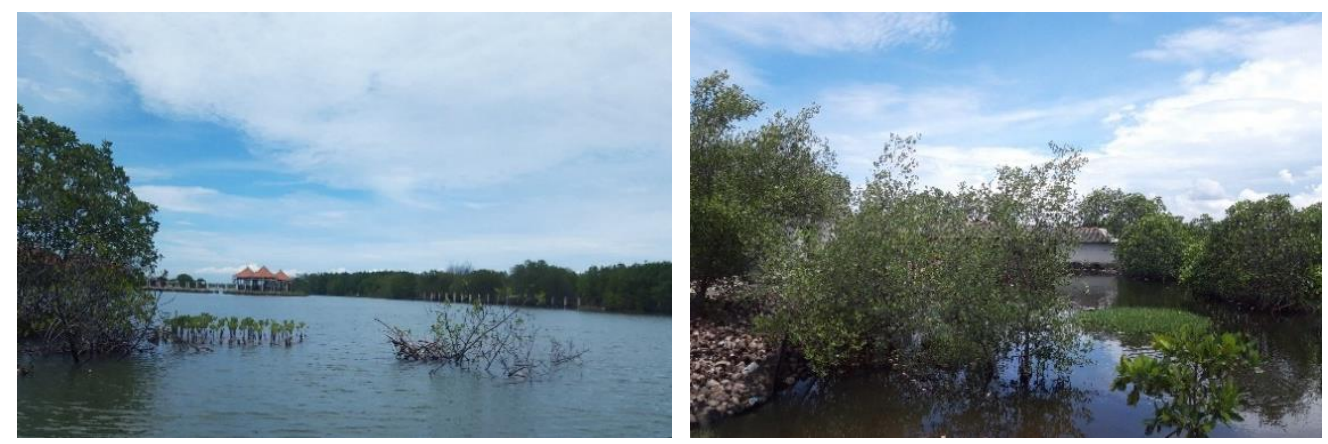

Gambar 2. Kondisi ekosistem mangrove di pesisir Kota Pekalongan Sumber: Dokumentasi Peneliti, 2020 
Tabel 3. Jenis Mangrove di Kecamatan

Pekalongan Utara, Kota Pekalongan

\begin{tabular}{cll}
\hline No & \multicolumn{1}{c}{ Nama Jelas } & Nama Daerah \\
\hline Mangrove Sejati & \\
1 & Achrostichum Aureum & Paku laut \\
2 & Avicennia Marina & Api-Api Putih \\
3 & Nypa Fruticans & Nipah \\
4 & Rhizopora Mucranota & Bakau Hitam \\
Mangrove Ikutan & \\
5 & Ipomoea Pes-Caprae & Batata Laut \\
6 & Ricimus Communis & Jarak \\
7 & Sesuvium & Seruni Laut \\
8 & Portulacastrum & \\
8 & Terminalisa Catappa & Ketapang \\
Vegetasi Lain & \\
9 & Thespesia Populnea & Waru Laut \\
\hline
\end{tabular}

Sumber: Mardiatno dkk., 2012

Tabel 4. Luasan Tiap Jenis Penggunaan Lahan di Lokasi Penelitian

\begin{tabular}{clrr}
\hline No & $\begin{array}{c}\text { Jenis } \\
\text { Penggunaan } \\
\text { Lahan }\end{array}$ & Luas (ha) & Luas (\%) \\
\hline 1 & Danau & 12,34 & 0,88 \\
2 & Industri & 24,09 & 1,71 \\
3 & Kantor & 5,92 & 0,42 \\
4 & Lapangan & 2,71 & 0,19 \\
5 & Makam & 3,89 & 0,28 \\
6 & Masjid & 1,85 & 0,13 \\
7 & Pantai & 9,13 & 0,65 \\
8 & Pariwisata & 11,26 & 0,80 \\
9 & Pelabuhan & 23,94 & 1,70 \\
& Perikanan & & \\
10 & Permukiman & 455,51 & 32,33 \\
11 & Perdagangan & 7,22 & 0,51 \\
& dan Jasa & & \\
12 & Pertanian & 177,61 & 12,61 \\
13 & Ruang & 15,27 & 1,08 \\
& Terbuka & & \\
14 & Taman Kota & 0,84 & 0,06 \\
15 & Tambak & 602,24 & 42,75 \\
16 & TPA & 4,33 & 0,31 \\
17 & Lainnya & 50,75 & 3,60 \\
& Total & $\mathbf{1 4 0 8 , 9 1}$ & $\mathbf{1 0 0}$ \\
\hline
\end{tabular}

Sumber: Rencana Tata Ruang Wilayah Kota Pekalongan Tahun 2009-2029

Luas penggunaan lahan di lokasi penelitian sebesar 1408,91 ha, terbagi menjadi 6 kelurahan. Dominasi penggunaan lahan berupa lahan perikanan tambak dan permukiman yang secara rinci dijelaskan dalam Tabel 4. Lahan perikanan tambak mendominasi penggunaan lahan yang lain sebesar 42,75\% kemudian penggunaan lahan permukiman sebesar 32,33\%. Permukiman dan lahan perikanan tambak merupakan jenis penggunaan lahan yang dianggap paling memberikan kerugian ketika terjadi banjir genangan sehingga penilaian ekonomi terhadap besarnya kehilangan penting untuk dilakukan.

Wilayah pesisir Kota Pekalongan memiliki ancaman bencana berupa banjir genangan, meliputi banjir yang berasal dari air laut maupun luapan air sungai. Banjir genangan yang kerap terjadi ini sangat mengganggu aktivitas masyarakat. Hal ini juga bersesuaian dengan kejadian di wilayah pesisir Tamil Nadu, India. Penilaian ekonomi terhadap ekosistem mangrove dilakukan pada fungsi ekologi mangrove yang berperan dalam meredam gelombang dan banjir. Penilaian ekonomi menunjukkan nilai yang sangat tinggi terhadap fungsi ekologi mangrove sehingga penting untuk dipertahankan kelestariannya (DebRoy, 2012).

Pemanfaatan lahan yang bertambah intensif seiring dengan perkembangan zaman meningkatkan risiko bencana. Hal yang paling dirasakan adalah permukiman masyarakat yang tergenang dan penurunan produktivitas perikanan tambak. Luasan tambak terbesar berada pada kelurahan Bandengan, Degayu, dan Krapyak yaitu masing-masing dengan luasan lebih dari 100 ha, sedangkan luasan permukiman terbesar yaitu Panjang Wetan dan Krapyak. Secara terperinci luasan tambak dan permukiman pada setiap kelurahan dijelaskan pada Tabel 5.

Tabel 5. Luasan tambak dan permukiman setiap Kelurahan di Kota Pekalongan

\begin{tabular}{lcccc}
\hline \multirow{2}{*}{ Kelurahan } & \multicolumn{2}{c}{ Tambak } & \multicolumn{2}{c}{ Permukiman } \\
& ha & \% & ha & \% \\
\hline Degayu & 167,87 & 27,87 & 57,45 & 12,61 \\
Krapyak & 158,43 & 26,31 & 107,17 & 23,53 \\
$\begin{array}{l}\text { Panjang } \\
\text { Wetan }\end{array}$ & 0 & 0 & 108,34 & 23,79 \\
$\begin{array}{l}\text { Panjang } \\
\text { Baru }\end{array}$ & 31,58 & 5,24 & 69,92 & 15,35 \\
$\begin{array}{l}\text { Kandang } \\
\text { Panjang }\end{array}$ & 75,01 & 12,45 & 68,37 & 15,01 \\
Bandengan & 169,35 & 28,12 & 44,24 & 9,71 \\
\hline Total & $\mathbf{6 0 2 , 2 4}$ & $\mathbf{1 0 0}$ & $\mathbf{4 5 5 , 5 1}$ & $\mathbf{1 0 0}$ \\
\hline
\end{tabular}

Sumber: Analisis Data, 2020 
Penilaian ekonomi besarnya jasa pengaturan ekosistem mangrove didasarkan pada nilai kehilangan untuk penggunaan lahan berupa permukiman dan lahan tambak. Pendekatan yang digunakan adalah contingen valuation method yang berarti menghitung nilai pengganti terhadap jenis penggunaan lahan permukiman dan lahan tambak jika ekosistem mangrove hilang. Nilai kehilangan untuk permukiman didasarkan pada besarnya biaya untuk membangun baru tiap bangunan dalam rupiah. Karakteristik permukiman dianggap homogen dengan kualitas sedang. Standar biaya bangunan di wilayah pesisir Kota Pekalongan berdasarkan hasil indepth interview dirinci pada Tabel 6.

Tabel 6. Standar Biaya Bangunan di Kota Pekalongan

\begin{tabular}{lr}
\hline \multicolumn{1}{c}{ Elemen Bangunan } & Biaya $\mathbf{R p / m 2 )}$ \\
\hline Struktur dan rangka atap & 1.300 .000 \\
Penutup atap & 225.000 \\
Plafon & 125.000 \\
Dinding & 550.000 \\
Lantai & 275.000 \\
Utilitas & 200.000 \\
Biaya tidak langsung & 325.000 \\
Total & $\mathbf{3 . 0 0 0 . 0 0 0}$
\end{tabular}

Biaya langsung meliputi komponen bangunan yaitu struktur dan rangka atap, penutup atap, plafon, dinding, lantai, utilitas, sedangkan biaya tidak langsung meliputi jasa konstruksi dan perijinan. Besarnya nilai kehilangan penggunaan lahan permukiman pada setiap kelurahan dijelaskan pada Tabel 7.

Valuasi ekonomi untuk penggunaan lahan berupa tambak didasarkan pada nilai jual komoditas dikali dengan produktivitas. Pendekatan contingen valuation method juga digunakan dalam penilaian yang berarti menghitung nilai pengganti terhadap jenis penggunaan lahan tambak jika ekosistem mangrove di sekeliling tambak hilang. Luasan lahan tambak sebesar 602,24 ha terdiri dari lahan produktif tambak sebesar 350 ha dan sisanya merupakan lahan idle (belum produktif). Pemanfaatan lahan sebagai perikanan tambak didominasi oleh komoditas bandeng dan udang, dengan produktivitas bandeng sebesar 601.300 $\mathrm{kg} /$ tahun dan udang sebesar $123.400 \mathrm{~kg} /$ tahun. Harga bandeng per kg yaitu Rp 15.000,00 dan harga jual udang per $\mathrm{kg}$ sebesar Rp 80.000,00. Penilaian ekonomi untuk perikanan tambak dirinci pada Tabel 8.

Sumber: Indepth Interview, 2020

Tabel 7. Nilai Kehilangan Penggunaan Lahan Permukiman di Pesisir Kota Pekalongan

\begin{tabular}{clrr}
\hline No & Kelurahan & Permukiman (m2) & Biaya Pengganti dalam jutaan rupiah \\
\hline 1 & Degayu & 574.500 & 1.723 .500 \\
2 & Krapyak & 1.071 .700 & 3.215 .100 \\
3 & Panjang Wetan & 1.083 .400 & 3.250 .200 \\
4 & Panjang Baru & 699.200 & 2.097 .600 \\
5 & Kandang Panjang & 683.700 & 2.051 .100 \\
6 & Bandengan & 442.400 & 1.327 .200 \\
\hline Total & & $\mathbf{4 . 5 5 5 . 1 0 0}$ & $\mathbf{1 3 . 6 6 4 . 7 0 0}$
\end{tabular}

Sumber: Hasil Analisis, 2020

Tabel 8. Nilai Kehilangan Penggunaan Lahan Perikanan Tambak di Pesisir Kota Pekalongan

\begin{tabular}{llrrr}
\hline No & Komoditas & $\begin{array}{c}\text { Produksi } \\
\text { (ton/ha/tahun) }\end{array}$ & $\begin{array}{c}\text { Harga dalam } \\
\text { juta (Rp/ton) }\end{array}$ & $\begin{array}{c}\text { Nilai Pengganti dalam } \\
\text { jutaan rupiah }\end{array}$ \\
\hline 1 & Bandeng & 601,3 & 15 & 350 ha $\times$ 724,7 ton/ha/tahun \\
2 & Udang & 123,4 & 80 & $\times 95$ Rp/ton \\
\hline Total & & $\mathbf{7 2 4 , 7}$ & $\mathbf{9 5}$ & $\mathbf{2 4 . 0 9 6 . 2 7 5}$ \\
\hline
\end{tabular}

Sumber: Indepth Interview, 2020 
Malik, dkk (2015) juga melakukan perhitungan TEV terhadap ekosistem mangrove di Sulawesi Selatan. Valuasi ekonomi dilakukan dengan membandingkan nilai pada jasa ekosistem mangrove dan nilai pada lahan ekosistem mangrove yang telah berubah menjadi lahan komersial berupa perikanan tambak. Hasilnya sesuai dengan penelitian ini bahwa nilai tidak langsung, salah satunya adalah jasa pangaturan berupa pengurangan risiko bencana menyumbang nilai tertinggi dalam perhitungan nilai ekonomi total.

\section{Simpulan}

Wilayah pesisir Kota Pekalongan memiliki potensi ekosistem mangrove yang berfungsi sebagai jasa penyedia, jasa pendukung, jasa kebudayaan, dan jasa pengaturan. Distribusi ekosistem mangrove di wilayah pesisir Kota Pekalongan berada di sepanjang pantai, tepi tambak, tepi sungai, dan Pusat Informasi Mangrove. Peran jasa pengaturan ekosistem mangrove dalam mengurangi risiko bencana banjir genangan antara lain meredam gelombang air laut, menguatkan tanggul pada tepi tambak, dan mengurangi erosi pada tanggul sungai sehingga air genangan tidak masuk ke permukiman dan perikanan tambak. Penilaian ekonomi jasa pengaturan ekosistem mangrove yaitu sejumlah $13.664,7$ milyar rupiah untuk penggunaan lahan berupa permukiman, sedangkan untuk perikanan tambak sebesar 24.096,275 milyar rupiah.

Valuasi ekonomi mampu memberi gambaran seberapa besar nilai ekonomi suatu ekosistem, selain itu juga bisa menggambarkan besarnya nilai kehilangan yang akan dirasakan masyarakat jika tidak mempertahankan suatu ekosistem. Penilaian ekonomi jasa ekosistem mangrove ini akan lebih baik jika dilakukan secara berkala dan kontinyu, mengingat perubahan nilai ekonomi (harga) dan produktivitas penggunaan lahan setiap tahunnya berbeda-beda. Perhitungan terkait nilai ekonomi jasa ekosistem ini diharapkan dapat membantu dalam pengelolaan ekosistem mangrove yang berkelanjutan.

\section{Ucapan terima kasih}

Penulis mengucapkan terima kasih kepada semua pihak yang telah berpartisipasi dalam kegiatan penelitian, baik dalam bentuk pemberian data dan informasi, maupun arahan dan saran dalam menyusun artikel ini.

\section{Referensi}

Arief, Arifin. 2003. Hutan Mangrove Fungsi dan Manfaatnya. Yogyakarta: Kanisius.

Badan Pusat Statistik Kota Pekalongan. 2019. Kecamatan Pekalongan Utara dalam Angka 2019. Kota Pekalongan: Badan Pusat Statistik Kota Pekalongan.

Barbier, E.B., Hacker, S.D., Kennedy, C., Koch, E.W., Stier, A.C., Silliman, B.R. 2011. The value of estuarine and coastal ecosystem services. Ecological Monographs., 81 (2011), pp 169193.

DebRoy, P. \& R. Jayaraman. 2012. Economic Valuation of Mangroves for Assessing the Livelihood of Fisherfolk: A Case Study in India. In: Visible Possibilities: The Economics of Sustainable Fisheries, Aquaculture and Seafood Trade: Proceedings of the Sixteenth Biennial Conference of the International Institute of Fisheries Economics and Trade, July 16-20, Dar es Salaam, Tanzania. Edited by Ann L. Shriver. International Institute of Fisheries Economics and Trade (IIFET), Corvallis.

Harahap, Nuddin. 2010. Penilaian Ekonomi Ekosistem Hutan Mangrove dan Aplikasinya dalam Perencanaan Wilayah Pesisir. Yogyakarta: Graha Ilmu.

Keputusan Walikota Pekalongan Nomor 532/ 02.a Tahun 2013 tentang Konservasi Kawasan Mangrove pada Pusat Informasi Mangrove dan Sekitarnya di Kota Pekalongan

Lugina, M., Indartik, Pribadi, M.A. 2019. Valuasi Ekonomi Ekosistem Mangrove dan Kontribusinya Terhadap Pendapatan Rumah Tangga: Studi Kasus Desa Pemogan, Tuban, dan Kutawaru. Jurnal Penelitian Sosial dan Ekonomi Kehutanan Vol. 16, No. 3, 2019: 197210 .

https://doi.org/10.20886/jpsek.2019.16.3.197 $-210$

Malik A, Fensholt R, Mertz O. 2015. Economic Valuation of Mangroves for Comparison with Commercial Aquaculture in South Sulawesi, 
Indonesia. Forests 2015; 6(9):3028-3044. https://doi.org/10.3390/f6093028

Mardiatno, D., Marfai, M.A., Rahmawati, K., Tanjung, R., Sinaturi, R.S., dan Mutiarni, Y.S. 2012. Penilaian Multirisiko Banjir dan Rob di Kecamatan Pekalongan Utara. Yogyakarta: MPPDAS Fakultas Geografi UGM.

Marfai MA and King L. 2008a. Coastal flood management in Semarang, Indonesia. Environmental Geology. 55: 1507-1518.

Marfai MA, Yulianto F, Hizabron DR, Ward P, Aerts. 2009. Preliminary Assessment and Modeling the Effects of Climate Change on Potential Coastal Flood Damage in Jakarta. Joint Research Report. Vree Univ Amsterdam and Gadjah Mada univ.

Marfai, M.A. 2014․ Impact of Sea Level Rise to Coastal Ecology: A Case Study on The Northern Part of Java Island, Indonesia. Quaestiones Geographicae 33 (1), Bogucki Wydawnictwo Naukowe, Poznan, pp. 107-
114, 5 figs, 3 tables. DOI 10.2478/quageo2014-0008, ISSN 0137-477X

Marre, J., Thebaud, O., Pascoe, S., Jennings, S., Bonceoeur, J., and Coglan, L. 2015. The Use of Ecosystem Services Valuation in Australian Coastal Zone Management. Marine Policy 56 page 117-124. Elsevier Ltd 0308-597X 2015.

Millenium Ecosystem Assessment. 2005. Ecosystem and Human Well-Being: Current State and Trends. Washington: Islandpress.

Peraturan Daerah Kota Pekalongan Nomor 30 Tahun 2011 tentang Rencana Tata Ruang Wilayah Kota Pekalongan Tahun 2009-2029

Satriagasa, M.C. 2015. Analisis Jasa Ekosistem Kawasan Kepesisiran Daerah Istimewa Yogyakarta dalam Pengurangan Risiko Bencana. Tesis. Yogyakarta: Universitas Gadjah Mada.

TEEB. 2010. The Economics of Ecosystems and Biodiversity: Ecological and Economic Foundation. Edited by Pushpam Kumar. Earthscan, London and Washington. 